\title{
NATUURBESCHERMING OP DE NEDERLANDSCHE ANTILLEN, HAAR ETHISCHE, AESTHETISCHE, WETENSCHAPPELIJKE EN ECONOMISCHE PERSPECTIEVEN
}

(Met 6 platen buiten de tekst) DOOR

\section{DR. J. H. WESTERMANN 1)}

Het is wellicht niet overbodig als inleiding tot deze verhandeling in het kort uiteen te zetten welke de algemeene beteekenis is van het beschermen der Natuur - en daarmee bedoelen we dan de anorganische wereld met de daarop levende planten- en dierengemeenschappen - tegen het ingrijpen, bewust of onbewust, door den mensch.

Natuurbescherming als wijdvertakte organisatie is betrekkelijk jong. We kunnen haar beschouwen als een reactie op de onbezonnen verwoesting van bosch en bodem, en een verzet tegen de noodelooze vernietiging van de in het wild levende dieren en planten.

Vooral sedert het midden der 19de eeuw is enorm veel verloren gegaan. Teneinde een besef te krijgen van de urgentie van het probleem, denke men maar eens aan de verschrikkelijke slachtingen destijds aangericht onder de Amerikaansche bisonkudden, aan de ontstellende achteruitgang van de groote Afrikaansche zoogdierfauna, de snelle verdwijning der hoogstmerkwaardige buideldiergemeenschap in Australië, de onverzadigbare behoeften van de pelterijenhandel, de moderne, geperfectioneerde walvisch-en robbenvangst. Inderdaad nadert het einde van het tijdperk der wilde zoogdieren met rassche schreden, en dat is te erger, omdat het geheel op rekening moet worden geschreven van onze eigen kortzichtigheid.

Wat de vogels betreft, de mode van veeren op de hoed leidde destijds tot de vernietiging van millioenen der fraaiste en meest interessante medeschepselen. De geschiedenis van de paradijsvogelhandel in Nieuw-Guinea geeft daaromtrent een duidelijke getuigenis, en het is jammer te moeten constateeren, dat de Nederlandsch-Indische autoriteiten lange tijd in gebreke zijn gebleven deze vogels te bescher-

1) Directeur van het Internationaal Bureau voor Natuurbescherming, Heerengracht 540, Amsterdam.

$$
-193-
$$


men tegen de winzucht van belanghebbenden. De paradijsvogeljacht was een typisch voorbeeld van hetgeen de Angelsaksische volken aanduiden met ,,commercialization of game”, dat is dus , het systeem om de wilde dieren tot voorwerp van de koophandel te maken", neerkomend op het roekeloos vangen en dooden terwille van een zoo groot mogelijke directe winst.

Niet alleen de dieren worden ten zeerste bedreigd. Ook het voortbestaan der plantenwereld vervult ons met groote zorg. De uitroeiïng van bosschen in alle werelddeelen, zonder dat hiermee gepaard gaat een verantwoorde uitbreiding van het landbouwareaal - een zuivere roofbouw derhalve - samengaand met intensieve bodemverarming, beteekent een hoogst ernstige economische achteruitgang, afgezien nog van het onherstelbare verlies van tal van levensvormen.

Het zal dus duidelijk zijn, dat de natuurbeschermingsbeweging - die zich keert tegen het wanbeheer der natuurlijke rijkdommen en tegen de misdaden, bedreven door den mensch tegen zijn lager-ontwikkelde medeschepselen in de vrije natuur - verschillende aspecten vertoont. Er is de ethische kant, de eerbied voor de schepping om haars zelfs wil; de aesthetische waarde, die uitstekend vertolkt wordt door de naam van de Amsterdamsche dierentuin „Natura Artis Magistra” (de Natuur is de leermeesteres der Kunst); de wetenschappelijke zijde, strevend naar het behoud van de studie-objecten, die de natuur ons nog zoo rijkelijk biedt en welker navorsching zulke ver-rijkende en heilzame consequenties voor de menschheid kan meebrengen. En dan is er nog de economische beteekenis.

Wat nu in het bijzonder betreft de Nederlandsche Antillen, is het zonder meer duidelijk, dat op de bewoners de plicht rust de natuurlijke schoonheid der eilanden zooveel mogelijk intact te houden; een plicht, die niet alleen voortvloeit uit het besef, dat ook de toekomstige generaties moeten kunnen genieten van hetgeen ons heden boeit en geluk schenkt, maar die ook sterk bepaald wordt door de overweging, dat wij tegenover de buitenwereld, de internationale wereld, verantwoordelijk zijn voor het juiste beheer en de bescherming onzer nationale natuurschatten. De overweging, dat de natuur der eilanden een onderdeel vormt der schepping en dat wij haar als zoodanig in eere dienen te houden, gekoppeld aan onze verantwoordelijkheid ten aanzien van hen, die komen, en aan onze internationale verplichtingen, deze drie zaken bij uitstek vormen het ethis ch motief voor het streven naar natuurbehoud binnen het gebiedsdeel. 
Onverbrekelijk hiermede verbonden is het a e s t h e t is c h e $\mathrm{b}$ e g i n s e l, dat geen samenleving - ook niet de Curaçaoschegezond en gelukkig kan zijn, indien zij niet in harmonische wisselwerking staat met de haar omringende natuur. Te weinig menschen beseffen nog de groote en gezegende invloed, die uitgaat van de vrije en ongeschonden natuur op den stadsbewoner en den landman, een invloed, die in zijn zuiverste vorm een voortdurende herschepping is, een wezenlijke re-creatie.

De reeks wetenschappelijke onderzoekingen, die sedert jaren zijn uitgevoerd op de Nederlandsche Antillen, op geologisch, botanisch en zoölogisch gebied, bewijzen hoezeer deze eilanden de belangstelling hebben van Nederlandsche en buitenlandsche natuuronderzoekers. Het is hier niet de plaats om uit te weiden over deze onderzoekingen. Wel kan hier naar voren gebracht worden, dat de drie Benedenwindsche Eilanden van bijzondere wetenschappelijke beteekenis zijn. Dit is eenerzijds het gevolg van hun ligging in een langgerekt gebied met tropisch steppenklimaat, dat zich Oost-West uitstrekt in het zuidelijk gedeelte der Caraïbische Zee en langs het Zuid-Amerikaansche kustland. Immers daardoor heeft de natuurlijke vegetatie der eilanden een typisch xerophiel (d.i. droogteminnend) karakter en is o.a. gekenmerkt door een bij uitstek interessante cactusflora, de vertegenwoordigers waarvan vrijwel alle reeds in de tijd van den grooten systematicus LinnaEus (1707-1778) beschreven waren. Onafhankelijk van de invloed van het klimaat heeft de plantenwereld echter tevens een zekere zelfstandigheid ontwikkeld, zoodat sommige soorten alleen op de Benedenwindsche Groep worden gevonden. Sterker komt deze zelfstandigheid nog naar voren in de dierenwereld, die vele endemische vormen kent, beperkt tot één of meer der eilanden 1). Het is dus wel haast overbodig hieraan toe te voegen hoezeer ook de we t e n s ch a p gediend is met de bescherming van de natuur onzer eilanden. In dit verband is het aangenaam te kunnen constateeren, dat de ,Natuurwetenschappelijke Studiekring voor Suriname en Curaçao" bij haar oprichting in Augustus 1945 het belang van de natuurbescherming voor de wetenschap heeft erkend, en dat zij krachtens de acte van stichting haar doel - d.i. de uitbreiding van de kennis der natuurlijke gesteldheid, zoowel met het oog op de belangen der wetenschap als op die van haar toepassing - onder meer

1) Zie bijvoorbeeld het artikel van P. WagenaAR Hummelinck ,Zoögeografische opmerkingen over de Nederlandsche Benedenwindsche Eilanden", W. I. Gids jrg. 25, dl 26, 1943; p. 168. 
tracht te bereiken door medewerking bij het stichten van natuurreservaten.

Ten laatste, maar niet het minste, verdient onze aandacht de e con omische zijde van het natuurbeschermingsprobleem der eilanden. Een nadere uiteenzetting hiervan is gewenscht.

Een ieder, die met de eilanden bekend is en die eenigszins op de hoogte is van de historische ontwikkeling, zal moeten toegeven, dat de natuurlijke begroeiïng in de loop der jaren niet onaanzienlijk is achteruitgegaan. Weliswaar heeft de vegetatie der Benedenwindsche Eilanden van nature een betrekkelijk armoedig, droogteminnend karakter — zooals reeds boven opgemerkt werdterwijl dichte, vochtig-tropische wouden er altijd hebben ontbroken, maar dat neemt niet weg, dat in de afgeloopen eeuwen een veel dichtere begroeiing de vlakten en heuvels heeft bedekt. Dit laatste geldt ook voor de Bovenwindsche Eilanden, waar van de oorspronkelijke vegetatie - die dank zij de grootere regenval het karakter van tropisch regen- of seizoenbosch had - slechts hier en daar resten zijn overgebleven, met name op Saba en St. Eustatius. Op St. Maarten hebben, ten behoeve van de veeteelt, groote grasvlakten van het guineagras de plaats der weggekapte bosschen ingenomen, terwijl de heuvels thans goeddeels bedekt zijn met weliswaar vrij dicht maar niet-oorspronkelijk bosch. Ook Saba en St. Eustatius dragen buiten de cultuurgronden veel secundair bosch.

De Indianen, die de eilanden vroeger bewoonden, zullen vermoedelijk niet ernstig ingegrepen hebben in het landschaps- en begroeiïngsbeeld. TEENSTRA 1) vermeldt bijvoorbeeld, dat CoLUMBUS in het jaar 1493 St. Maarten door Caraïben bewoond vond, ,,die onder bedekking van hooge bosschen, waarmede hetzelve begroeid was, hunne hutten hadden opgeslagen" 2). Pas de komst der Spanjaarden bracht aanzienlijke veranderingen, allereerst door de kap van het kostbare verfhout of campèshi (Haematoxylon brazilletto) en het pokhout (Guaiacum officinale), bestemd voor de uitvoer, en door de winning van brandhout en houtskool. Ingrijpend ook was de aanleg van plantages, die na de

1) M. D. Teenstra , De Nederlandsche West-Indische Eilanden” 1836-1837 (twee stukken), II; p. 270.

2) Het zij hier echter vermeld dat men tegenwoordig niet meer gelooft, dat het San Martín van Columbus' tweede reis het tegenwoordige eiland St. Martin geweest zou zijn. 
verovering der eilanden door de Hollanders ${ }^{1}$ ), groote arealen in beslag gingen nemen, en voorts de invoer van geiten en schapen.

$\mathrm{Al}$ deze factoren zijn verantwoordelijk voor de achteruitgang en de plaatselijk bijna volledige verdwijning der begroeiïng. Pater P. A. EuWENS O P. achtte voor Bonaire het kappen voor export en het houtskoolbranden het meest ingrijpend.

Het is de moeite waard om eenige zijner belangwekkende beschrijvingen uit ,De tegenwoordige economische toestand van Bonaire" (Bonaire-nummer van Neerlandia jrg. II no 12, 1907; p. 202-203) hier over te nemen:

„Er is een tijd geweest, dat Bonaire dicht begroeid was met heestergewas en laag geboomte. Zelfs nu, nadat jaren lang overal in het wild is weggekapt, steekt Bonaire in dit opzicht nog gunstig af bij de twee naburige eilanden. Reeds in de tijd der Spanjaarden leverde Bonaire jaarlijks een aanzienlijke hoeveelheid hout, waarvan het Braziliehout, ook stokvisch- of rood verfhout genaamd, en het pokhout handelswaarde bezaten."

"Sinds eenige jaren heeft alle uitvoer van dit hout opgehouden. Al de dikke en zware stammen van Brazilie-en pokhout zijn geveld. Op vele plaatsen ziet men nog een spichtig stammetje. Doch bij den langzamen groei van dit hout en de tegenwoordige grootere bevolking, in aanmerking genomen ook, dat alle timmerhout van Noord-Amerika moet worden ingevoerd, is het geenszins te verwonderen, dat die weinige stammetjes maar zelden den vollen wasdom bereiken, niettegenstaande de strenge straffen van gouvernementswege op het kappen van boomen uitgevaardigd."

„,Ook wordt op Bonaire veel houtskool gebrand, en hieraan vallen jaarlijks heel wat boomen ten offer. Wel is waar wordt een permit, om houtskool te branden, in de laatste jaren niet gemakkelijk gegeven, terwijl bovendien toch slechts minderwaardig hout - zooals doode stammen en takken en oude boomstronken - daarvoor mag gebruikt worden. Eensdeels echter is het gouvernement in tijden van misoogst en gebrek dikwijls gedwongen aan de noodlijdende bevolking een dergelijk permit uit te reiken. Andersdeels valt het niet zoo bijster moeilijk ook zonder permit klaar te komen, bij de onmogelijkheid voor het plaatselijk bestuur om scherp toezicht te houden. Jaarlijks worden ongeveer 30.000 zakken houtskool van Bonaire naar Curaçao uitgevoerd, ongerekend nog de hoeveelheid, die op het eiland verbruikt wordt. Hoe langer zoo meer neemt de boomgroei ook op Bonaire af. Plaatsen, die bij menschenheugenis nog dicht begroeid waren, zijn nu dor en kaal. Reeds in de naaste toekomst zal het gebeuren, dat het eiland ternauwernood brandhout en houtskool voor eigen gebruik zal kunnen opleveren."

Ook in een latere publicatie over ,,De Brandaris, de hoogste bergtop van het eiland Bonaire" (W. I. Gids, jrg. 15, dl I6, 1934; p. 257 en

1) De drie Benedenwindsche Eilanden kwamen in 1634 onder ons gezag; St. Maarten was Nederlandsch van $1630-1633$ en vanaf 1648 ; St. Eustatius (met Saba) werd in 1636 door de onzen bezet. 
289) legde Euwens de nadruk op de invloed van de houtkap op het landschapsbeeld:

„De top mag zeer zeker kaal worden genoemd; zeer verspreid staan er slechts enkele windboompjes en hier en daar wat lage struiken. Eén man kan hier in korten tijd méér kappen dan de natuur er in tientallen van jaren weer kan opbrengen. Met dit kappen zullen we trouwens steeds rekening moeten houden; dit heeft het plantendek dezer eilanden, inzonderheid Bonaire, in den loop der jaren, stellig op een zeer nadeelige wijze beinvloed."

Naast de houtkap is het echter de vraatzucht der tallooze, vrijwel wild rondzwervende geiten en schapen, die tot de verarming der vegetatie aanzienlijk heeft bijgedragen en nog bijdraagt. Ook elders in de wereld is de teugellooze veeweide oorzaak van groote landverwoesting. Frappante voorbeelden kennen we uit Australië. Het is misschien niet aan velen bekend, dat geiten in hooge mate mede-verantwoordelijk zijn voor de denudatie en algemeene verarming van het Middellandsche Zee-gebied en de landen rondom de Sahara.

Uit de gegevens in de Koloniale Verslagen zou men zich een beeld kunnen vormen van de fluctuatie der aantallen geiten (cabrieten) en schapen. In het jaar 1634 (het jaar van de verovering van Curaçao) zouden er ongeveer duizend geiten en negenduizend schapen op dat eiland geweest zijn. Dit aantal is in de loop der eeuwen aanmerkelijk toegenomen, en wij vinden bijv. voor 1863 opgegeven 22615 geiten en 30224 schapen, voor 1899 respectievelijk 43638 en 23440 . Waren oorspronkelijk de schapen in de meerderheid, later is dat anders geworden, en in 1930 werden op Curaçao driemaal zooveel geiten als schapen geteld, respectievelijk 21000 en 7100 . De fluctuaties in de aantallen dezer halfverwilderde dieren hangen uiteraard sterk samen met de klimaatstoestanden. Hoewel geiten en schapen (vooral de eerstgenoemde) beter dan ander vee droge tijden kunnen doorstaan, zoo hebben zij toch van langdurige droogte te lijden. De droge periode 1899-1903 toont dat zeer duidelijk: het aantal geiten liep terug van 43638 tot 24054 , dat der schapen van 23440 tot 13462 ! Onder gunstige omstandigheden stijgt hun aantal echter weer snel, dank zij hun goed voortplantingsvermogen. Bij de cabrieten zijn twee jongen per worp geen uitzondering en soms vinden zelfs twee worpen per jaar plaats.

In hoeverre is nu de verarming van de vegetatie door de boven besproken oorzaken een economische achteruitgang?

Zeer in het kort komt het hierop neer. Een behoorlijk planten- 
dek en een goed boschbestand vormen een wezenlijke voorwaarde voor, ten eerste, het behoud van de bodem, ten tweede, de instandhouding van een voldoend hoog grondwaterpeil. Planten, struiken en boomen beschermen de bodem tegen afspoeling en tegen uitdroging door zonnebestraling, en bevorderen voorts de opname van het regenwater in de grond, zoodat dit water zoo weinig mogelijk over de oppervlakte wegstroomt. Hierdoor wordt de hoeveelheid water in de bodem grooter dan anders het geval zou zijn, en omgekeerd kan de vegetatie zich beter handhaven, zelfs indien voor economisch gebruik een beperkte hoeveelheid water aan dit natuurlijk reservoir wordt onttrokken.

Met andere woorden, de bescherming der vegetatie tegen mensch en dier bevordert de water- en bodemconservatie, twee zaken, die van direct en toekomstig economisch belang zijn voor het gebiedsdeel. Toenemende ontwouding daarentegen zal leiden tot een achteruitgang der hydrologische condities en zal de bodemerosie sterk bevorderen. Grasland - zooals op St. Maarten moge een tamelijk goede beschutting vormen voor de bodem, het kan onmogelijk de water- en de bodem-conserveerende functie van bosch geheel vervangen.

Tot goed begrip dient hieraan toegevoegd te worden, dat het natuurlijk niet aangaat om terwille van de bodem- en waterconservatie onevenredig groote arealen uit te sluiten van cultivatie. Echter zal er naar moeten worden gestreefd om een juist grootteevenwicht te bereiken tusschen de zoo goed mogelijk begroeide watervanggebieden en de landbouwarealen, d.z. de water-,,consumptie"-terreinen. De watervanggebieden liggen natuurlijk bij voorkeur in het heuvel- en bergterrein, en in het algemeen ware dus de ontwouding en de cultivatie boven een nader vast te stellen hoogtelijn geheel te verbieden, ten behoeve der hydrolo'gische boschreservatie. Deze hooger-gelegen terreinen zullen op die wijze goede, natuurlijke waterreservoirs vormen, zelfs in de droge tijden, en daardoor de cultivatie van de lagere gronden blijvend mogelijk maken, eventueel door irrigatie uit putten.

$\mathrm{Er}$ is nog een ander economisch voordeel verbonden aan het behoud van natuurterreinen. Deze vormen immers het woon- en broedgebied van zoovele voor de landbouw nuttige vogels. Hiertoe behooren niet alleen de insectenetende soorten, zooals de vliegenvangers (Tyrannidae), de ani's, de para-di-misa's, maar ook de kini-kini's en killy-killy's (Falco sparverius). Deze laatstgenoemde roofvogeltjes, waarvan een aparte ondersoort voorkomt op zoowel de Benedenwindsche als de Bovenwindsche Ei- 
landen, maken zich nuttig met het verdelgen van sprinkhanen en andere insecten, muizen en hagedissen.

Indien wij ons afvragen of op de Nederlandsche Antillen in de loop der jaren een grondpolitiek is gevoerd, die met het bovenstaande rekening hield, dan moeten we die vraag ontkennend beantwoorden. Wel bestaan er enkele Verordeningen en Keuren, die, indien doelbewust en op de juiste wijze toegepast, zeker tot een bevredigend resultaat hadden kunnen voeren. Van reeds lang geleden dateert de ,Verordening van 8 Mei 1867 op de uitgifte in eigendom of pacht van publieke gronden in de kolonie Curaçao" (Publicatieblad 1867 no 4; gewijzigd in Publicatieblad I894 no 26). Met de in artikel 5 hiervan voorkomende bepalingen ten aanzien van het huurcontract, is door den wetgever beoogd een zooveel doenlijk intact laten van het opgaande hout, naast een zoo rationeel mogelijke ontginning der uitgegeven gronden:

B. Geene opgaande boomen mogen geveld of uitgeroeid worden.

C. De huurder moet, in de plaats van doode boomen, krachtige levende boomen planten en onderhouden.

D. Bij het kappen van brand- of verfhout (d.i. de brasiya of campèshi, Haematoxylon brazilletto), indien de bevoegdheid daartoe aan den huurder toegekend is, mag geen ander hout dan snoeisel worden ingezameld; de stam of stammen moeten in behoorlijken wasdom worden gelaten.

E. Gronden, voor landbouw verhuurd, moeten bij het eerste daarvoor geschikte seizoen beplant worden, en zulks overeenkomstig de eischen van den landbouw.

Weinig of niet is echter de hand gehouden aan deze toch zoo redelijke voorschriften. De nieuwe Agrarische Wetgeving zal, naar te hopen is, eveneens regelend optreden ten aanzien van de bescherming van grond en begroeiïng. Zonder strikte naleving zal zij echter, evenals de Verordening van 1867, gedoemd zijn een doode letter te blijven.

Er zijn nog eenige andere wetgevende bepalingen, die van belang zijn voor de natuurbescherming. De Keuren van 22 December I877, 30 Jan. 1903 en 25 Maart I9I8, art. 2 en 4 (Aruba) en, laatstelijk gewijzigd, I3 Juni I9I8 (Bonaire), regelen d e pl u k, de verkoop, het vervoer en de uitvoer van onrijpedivi-divi (wat a pana) peulen, groeiende op Gouvernement s grond. Deze keuren beoogen in de eerste plaats een bescherming van het handelsproduct; echter zijn zij ook van belang voor de instandhouding van de divi- 
diviboom (Caesalpinia coriaria), één der belangrijkste elementen der natuurlijke vegetatie $\left.{ }^{1}\right)$.

De Keuren van 2 Mei I 908 en 25 Maart I9I8, art. 6 (Aruba), en, laatstelijk gewijzigd, I3 Juni I9I8 (Bonaire), bevatten bepalingen omtrent het hout kappen en kolenbranden op Gouvernementsgronden, en het vervoer van brandhout en houtskool. In art. 1 dezer keuren is het kappen van groen hout, cactus daaronder begrepen, en snoeisel op Gouvernementsgronden, verboden, tenzij daartoe door of namens den Gezaghebber een ,,permit” is verleend. Eveneens is een „,permit” benoodigd voor het aanleggen van kolenmeilers en het uitbranden van houtskool op Gouvernementsgronden. Door een beperking van de uitgifte der vergunningen heeft het Gouvernement het dus in de hand de aantasting van de houtopstanden belangrijk te verminderen.

Bepalingen inzake het weiden en schutten van $\mathrm{v}$ e e zijn opgenomen in de Keuren van 21 Juli I 908 en 25 Maart $I 9 I 8$, art. 5 (Aruba) en, laatstelijk gewijzigd, I,3 Juni I9I8 (Bonaire). Art. 1 luidt: ,Niemand mag vee op publieke gronden laten weiden, zonder een daartoe strekkende vergunning, door den Gezaghebber af te geven". Ook aan de hand van deze keuren kan een betere bescherming van de vegetatie der publieke gronden verzekerd worden, en wel door het beperken van de uitgifte der weide-vergunningen en door daaraan te verbinden een restrictie van plaats en tijd.

Het is goed het veeweide-probleem nog even nader te beschouwen, gezien de groote economische belangen, die verbonden zijn aan de geiten- en schapenhouderij, met name op de Benedenwindsche Eilanden. Belangrijke inkrimping dezer veeteelt is zeer zeker onwenschelijk, zoolang deze dieren nog zulk een waardevol bezit der bevolking vormen ${ }^{2}$ ). Slechts is het noodig de veeweide aan restrictie te binden. Zulk een restrictie zal van belang zijn voor het behoud van de natuurlijke begroeiïng en alzoo indirect een gunstige invloed hebben op de landbouw, zonder dat dit per sé een aanmerkelijke achteruitgang van het aantal dieren tot gevolg behoeft te hebben. Men kan op die manier ,,de geit en

1) Interessant is te weten, dat in de droge jaren 1901-1902 de Bonaire-keur tijdelijk geschorst is, in verband met de vernieling op groote schaal der onrijpe dividivipeulen door parkieten, die tengevolge van het mislukken van het gewas weinig ander voedsel konden vinden.

2) Vergelijk A. G. Statius Muller „,De Economische beteekenis van Landbouw en Veeteelt voor Curaçao", Beurs- \& Nieuwsberichten van 21 April, $5 \mathrm{Mei}$ en $20 \mathrm{Mei}$ I94I. 
de kool sparen"'! Op het oogenblik is de toestand dusdanig, dat uitgestrekte terreinen, behoorende tot het Gouvernementsdomein, vrijwel kaal zijn, als gevolg van ongecontroleerde houtkap en veeweide door de bevolking ${ }^{1}$ ). Willen wij deze toestand verbeteren, dan zal dat het gemakkelijkst geschieden door perceelen te omrasteren en het vee te weren. Een natuurlijke herbebossching zal dan volgen. Door dit omrasteren in étappes uit te voeren, zal aan de bevolkingsveeweide zoo weinig mogelijk in de weg gelegd worden. Nadat de begroeiïng zich wederom hersteld zal hebben, kunnen bij afwisseling perceelen voor veeweide en beperkte houtkap opengesteld worden.

Eenerzijds erkennend de economische noodzaak van de bescherming der natuurlijke vegetatie en aan de andere kant beseffend, dat over het algemeen de domeingronden veel minder aantrekkelijk zijn voor conservatie dan de uitgestrekte particuliere landerijen met hun rijkere begroeiïng, kunnen wij ons afvragen op welke wijze deze laatste in het kader van een, het geheele gebiedsdeel omvattend conservatie-schema kunnen worden betrokken. Uiteraard zal hierbij een ingrijpen in de eigendomsrechten niet vermeden kunnen worden, al zal dit in geenen deele het karakter van ,,onteigening ten algemeenen nutte en in het publiek belang" behoeven te hebben (art. 1 der On teigeningsverordening van 13 Juli 1887). Toch zou wellicht op een andere wijze hier iets bereikt kunnen worden, en we willen in

1) Wanneer men op Curaçao van Savonet naar Westpunt rijdt, is het verschil tusschen de goed-begroeide plantage Savonet, ter linkerzijde, en de vrijwel kale Gouvernementsgronden, ter rechterzijde, opvallend. Dit wordt niet veroorzaakt door verschillen in bodemgesteldheid maar door het verschil in beheer. De landbouwkundige R. H. RiJKens typeert in zijn bekend geschrift ,Curaçao. Verbetering van den landbouw aldaar als middel ter verheffing der Kolonie", 1907 (reeds eerder gepubliceerd in Cultura, jrg. 1905, onder de titel ,,De landbouw van (Curaçao en zijn toekomst"), heel aardig de gesteldheid der publieke terreinen:

„,De gouvernementsgrond komt in eenige complexen over het geheele eiland verspreid voor. Voor zoover hij niet in perceelen van 1 à $2 \mathrm{HA}$. of ook wel kleinere stukken, verhuurd is, ligt hij nog geheel woest en dient tot gemeenschappelijke weide voor het vee van plantagebezitters en van hen, die van het gouvernement grond in huur hebben. - Verreweg het grootste gedeelte van deze gemeene ,weide” ziet er dan ook zoo uit, dat men niet kan begrijpen hoe zelfs de genoegzame geit er nog iets vindt om af te weiden. Heele uitgestrektheden zijn zoo kaal als de palm van een hand; zelfs de cactussen zijn schaarsch." 
verband daarmede eens nagaan hoe deze materie in Nederland en op enkele Caraïbische eilanden geregeld is.

Nederland kent sedert 1928 de $\mathrm{N}$ at u u r c hoonwet. Deze wet schept de mogelijkheid voor eigenaren van landgoederen om de fiscale lasten rustend op hun bezit (vermogens-, personeele, inkomstenbelasting; successie- en zegelrecht), in belangrijke mate te verminderen, door hunne landgoederen uit vrije wil te rangschikken onder deze wet, daarmee te kennen gevende de bereidheid om het goed als zoodanig in stand te houden. Toelating van het publiek beteekent een extra verlaging der vermogensbelasting. Het totale aantal landgoederen, waarop de faciliteiten, welke de wet biedt, van toepassing zijn, bedroeg op 31 December 1945: 625, met een gezamenlijke oppervlakte van ongeveer 78.084 ha. - Intusschen heeft de wet voor een duurzame bescherming van het natuurschoon geen waarde, aangezien iedere eigenaar zelf aan de aanwijzing een einde kan maken, en dan weer de vrijheid heeft om aan zijn landgoed een andere bestemming te geven, zonder dat de reeds genoten financieele voordeelen voor hem verloren gaan; een uitzondering alleen vormt de eventueele vermindering van successierecht, die door den eigenaar moet worden gerestitueerd, indien onttrekking aan de wet binnen 25 jaar plaats heeft.

De Nederlandsche B o s ch wet van 1922,ingesteld in het belang van de boschbouw alsmede tot behoud van bosschen terwille van het natuurschoon, stelt slechts bosschen van publiekrechtelijke lichamen en van vereenigingen en stichtingen van algemeen nut onder toezicht (van het Staatsboschbeheer). Echter voorziet art. 9 in het behoud van alle met ondergang bedreigd wordende bosschen, dus ook die in particulier eigendom, namelijk door onteigening ten name van het Rijk, een gemeente of een rechtspersoonlijkheid bezittende vereeniging of stichting, uitsluitend in het belang van het natuurschoon werkzaam. Zulk een onteigening kan echter alleen plaatsvinden terwille van het algemeen nut, en uiteraard tegen een billijke schadeloosstelling. Verscheidene malen werd in Nederland zulk een onteigening toegepast.

In 1942 werd - door aanvulling van de O n t e i g e $\mathrm{n}$ in g sw e $\mathrm{t}$ - de mogelijkheid geschapen om in het belang van de natuurbescherming ook dan tot onteigening over te gaan, wanneer het natuurschoon niet door houtopstanden gevormd wordt, maar bijv. door duinen, heiden, plassen, vennen.

Ook op verschillende Antillen-eilanden bestaan bepalingen, die dienen om de houtopstanden te conserveeren. Barbados vaardig- 
de in 1875 een Act uit, die bepaalt, dat voor land, hetwelk met bosch (of boomen op een bepaalde afstand) beplant wordt, een jaarlijksche bijdrage van $£$ 1.-.- per acre wordt betaald, gedurende zeven jaar. Tevens geniet de eigenaar vrijdom van grondbelasting, zoolang het bosch in stand gehouden wordt. Op het Fransche territorium van St. Martin (behoorende tot het Departement Guadeloupe) is van kracht het Règlement relatif au régime forestier de la Guadeloupe, voté par le Conseil général le 28 Novembre I923, dat de rechten van de particuliere eigenaren op hunne bosschen aan restricties bindt, al moet het voorbehoud worden gemaakt, dat niet steeds - met name niet door de bezitters van kleine terreinen - de hand hieraan wordt gehouden. Het is o.m. verboden het bovenste derde gedeelte der berg- en heuvelhellingen en de ravijnhellingen van meer dan 45 graden te ontginnen.

Een uitmuntend voorbeeld van boschbescherming wordt gegeven door het Britsche eiland St. Kitts, alwaar het behoud der berg- en heuvelbosschen ten behoeve van de water- en bodemconservatie, de landbouw (hoofdzakelijk suikerteelt) en de houtproductie reeds sedert vele jaren als een belang van de eerste orde wordt gezien en nagestreefd. Evenals op St. Martin bevinden zich hier de bosschen vrijwel geheel in particuliere handen. De eigenaren zijn zich de gevaren van ontbossching - voor het eiland in het algemeen en voor de suikercultuur in het bijzonder - zoozeer bewust, dat zij ten volle samenwerken met de „Forestry Board". Op grond van de Forest Ordinance no Io van I9o3, aangevuld door no 22 van $I 92 I$ en no 5 van $I 928$, waakt deze Board voor de instandhouding der grootendeels particuliere „,schermbosschen", die alleen met uitdrukkelijke toestemming gekapt mogen worden voor ontginning. Wel echter is het den eigenaren steeds toegestaan bouw- en brandhout uit hunne bosschen te halen, mits dit alleen gebruikt wordt op eigen landerijen. In een nieuw-voorgestelde Forestry Ordinance ${ }^{1}$ ) is een bepaling opgenomen, die den Gouverneur het recht verleent om terreinen, al of niet beboscht, te bestemmen tot „Forest Reserve”. Dit zou dan gepaard gaan met kwijtschelding der grondbelasting.

Vergelijking met Nederland en de genoemde Caraïbische eilanden leert dus, dat prijsgave van een deel der eigendomsrechten ten behoeve van het algemeen belang (landbouw-, bosch-, bodem-

1) Deze gegevens zijn ontleend aan een rapport van den Conservator of Forests, Trinidad and Tobago, getiteld „,Forestry in the Leeward Islands", Serie Development and Welfare in the West Indies, Bulletin no 7, Febr. 1944. 
en natuurbescherming) een normale op wet gebaseerde procedure dient te zijn, waartegenover billijkerwijs een schadevergoeding moet staan. Zoodoende ware onteigening in vele gevallen te vermijden. Dit neemt echter niet weg, dat het Gouvernement in de komende jaren zooveel mogelijk van vrijwillige verkoop zal moeten gebruik maken voor het verkrijgen van waardevolle natuurterreinen.

Tot nu toe is onze aandacht grootendeels gewijd geweest aan het reserveeren van beboschte terreinen ten behoeve van economische doeleinden: water- en bodemconservatie, landbouw. Zulke reserves zouden met de naam „Hydrologische Boschreserves” betiteld kunnen worden. We willen echter daarnaast een plaats opeischen voor de eigenlijke natuurreservaten, alwaar flora en fauna om haars zelfs wil en voor de wetenschap beschermd dienen te worden. Zouden de Hydrologische Boschreserves op grond eener Boschverordening gesticht kunnen worden (naar het voorbeeld van St. Kitts), zoo zouden Natuurreservaten tot stand kunnen komen op basis van een Natuurbeschermingsverordening. In natuurreservaten zal strikt verbod van houtkap, veeweide, verzamelen, vangst, jacht, zoo noodig van toegang, gelden; in het kort, de menschelijke invloed zal er zooveel mogelijk uitgeschakeld of beperkt dienen te worden. Uiteraard geldt voor de natuurreservaten eveneens, dat in het algemeen de mooiste, best-begroeide en meest wildrijke terreinen deel vormen der particuliere landerijen. Ook voor de natuurreservaten zal derhalve een tijdelijke regeling moeten worden getroffen, waarvan zoowel het Gouvernement als de eigenaren profijt hebben, terwijl op den duur het Gouvernement zich bij vrijwillige te koop aanbieding van het bezit der belangrijkste terreinen zal dienen te verzekeren.

Als we spreken over natuurreservaten, dan kunnen we daarmede allerlei soorten terrein bedoelen. In dit opzicht is het goed ons te laten leiden door de terminologie, vastgesteld door de 1 Mei 1942 in werking getreden Pan-American Convention on Nature Protection and Wild Life Preservation in the Western Hemisphere, waartoe de meeste Amerikaansche republieken, behoorende tot de „Pan-American Union”, toetraden. Deze Conventie onderscheidt "National Parks", "Strict Wilderness Reserves", "N a t ure Monuments" en „National Reserves".

Het begrip „National Park" - omvattend de uitdrukkelijke bepaling, dat het landschap, de flora en fauna er weliswaar beschermd zijn, maar tevens dienen voor ,,enjoyment, 
benefit, recreation and education of the general public" - is voor de eilanden wel wat grootsch van conceptie, en zou in de toekomst slechts in aanmerking komen voor een uitgestrekt en fraai-begroeid heuvelcomplex in het Noordwesten van Curaçao of Bonaire, terreinen, die thans voor het allergrootste gedeelte in particulier bezit zijn. ,S trict Wilderness Reserve s" vragen strikte bescherming tegen alle menschelijke invloed en impliceeren bovendien een soort oertoestand van de begroeiïng en het dierenleven, die op de eilanden feitelijk niet meer aanwezig is. Dit soort reserve komt dus evenmin in aanmerking.

De meeste der te beschermen natuurterreinen zullen derhalve gerangschikt moeten worden onder ",N a t u re M o n u m e n t" (volgens de definitie kleine terreinen, planten- en diersoorten, objecten van aesthetische, historische of wetenschappelijke waarde) en "N a ti on a l R e s e r v e” (gebieden, beschermd voor ,"conservation and utilization of natural resources", waarin dus het economische motief naar voren komt). Terreinen speciaal voor de cactusflora, onbenutte bronnen en waterputten met omgeving, broedplaatsen van bijvoorbeeld flamingo's, reigers, Jan van Genten, zullen moeten worden vastgelegd als natuurmonument. Evenzoo geldt dit voor geologische en landschappelijke objecten. Historische en ethnologische objecten zooals oude forten, landhuizen, grotten met Indianenteekeningen, zouden volgens de definitie der Western Hemisphere Convention eveneens beschermd kunnen worden als natuurmonument, hoewel de naam Cultuurmonument hier beter op zijn plaats zou zijn 1).

Met de ,N a t i o n a l R e s e r v e s" komen we terecht bij de hoofdzakelijk voor economische doeleinden te reserveeren gebieden, waarover boven reeds geschreven werd. Met name vallen hieronder de „Hydrologische Boschreserves”, die van zulk een groot belang zijn voor de waterhuishouding, het behoud van de bodem en

1) De instandhouding van cultuurmonumenten ligt feitelijk buiten het kader van deze verhandeling, maar toch moge hier de aandacht gevestigd worden op de noodzaak om, terwille van de historische wetenschap, oude bouwwerken als forten, kerken en plantagewoningen, stammende uit vorige eeuwen, in redelijke staat te bewaren. Sommige der forten worden voldoende onderhouden en zijn nog in gebruik bij marine, leger of politie (Willemstad, Kralendijk, Fort Oranje op St. Eustatius). Andere forten en batterijen bevinden zich echter in sterk verwaarloosde toestand of zijn vrijwel geheel tot ruïnes vervallen. Dit laatste geldt ook voor kerken en andere gebouwen op St. Eustatius. 
derhalve ook van de landbouw. Echter behooren hier eveneens toe „Boschreserves", ten behoeve van de boschbouw (productie van hout en houtskool); ,,Jacht- en Vischreserves", voor de instandhouding van het jachtwild en de vischfauna; , ,Mijnreserves”.

Bij de aanwijzing van natuurmonumenten en reservaten zal dus nauwkeurig in overweging moeten worden genomen voor welk doel deze worden geschapen en de classificatie daarvan moeten afhangen.

Een inventarisatie van te beschermen terreinen op de Nederlandsche Antillen zal een vrij uitgebreide lijst opleveren. Het is hier niet de plaats een volledige opsomming te geven, maar een uitzondering kan worden gemaakt voor een aantal prominente objecten. We noemen de Hooiberg op Aruba. Het is een 165 meter hooge kegel, bestaande uit een merkwaardig donker, granietachtig gesteente, dat voorzoover bekend, elders ter wereld nog niet is gevonden, en waaraan derhalve een eigen, lokale naam is gegeven: Hooibergiet 1). Ook landschappelijk en om zijn begroeiing is de Hooiberg waard te worden ,,verheven” tot natuurmonument.

Een ander geologisch en geomorphologisch monument is de Ronde Klipberg op Curaçao. Deze is een diabaasheuvel, bedekt met een Noordwaartshellende kalksteenplaat, welke laatste een rest is van de voormalige Kwartaire kalksteenkap, die vele eeuwen geleden vrijwel het geheele eiland bedekte; het is een zoogenaamde ,,getuigeberg"'.

Op St. Eustatius, aan de Zuidkust, vormt de Whitewall, met het Sugarloaf, een prachtobject voor een geologisch natuurmonument. De formatie bestaat hier uit steil-hellende platen van afwisselend koraalkalksteenen, kalkige tuffen, dacietpuimsteen, andesiettuffen en -breccia. We mogen aannemen, dat deze platen een deel vormen van een nog in het Kwartaire tijdvak op een onderzeesche bank afgezette sedimentformatie (afwisselend vulkanische en mariene fossielhoudende sedimenten), die door een Pleistocene of Jong-Kwartaire (sub-recente) uitbarsting van de Quill-vulkaan opgetild zijn en nu in een hellende positie tegen het vulkaanlichaam rusten (men zie de afb. op blz. 216) 2).

1) Zie J. H. Westermann ,,The Geology of Aruba”, Utrecht 1932.

2) Deze configuratie toont aan, dat wel degelijk somtijds het vulkanisme plaatselijk belangrijke opheffingen kan teweegbrengen, al wil dit uiteraard niet zeggen, dat de oude Opheffingstheorie van L. von $\mathrm{BucH}$ er door in eere hersteld wordt. Vermoedelijk is de Brimstone 
Naar aanleiding van de genoemde geologische monumenten willen wij nog op het volgende de aandacht vestigen. Het spreekt vanzelf, dat de industrieele ontwikkeling der eilanden niet mag worden geremd door een te ver doorgevoerde piëteit voor het natuurlijke landschap. Wel moeten we echter opmerken, dat iedere afgraving (bijvoorbeeld ten behoeve eener cementindustrie) van de voor het landschap der eilanden zoo karakteristieke gesteentelagen, die ons over de geologische geschiedenis zooveel te vertellen hebben, zou betreurd worden door hen, die er de wetenschappelijke en aesthetische waarde van erkennen. Het is daarom te hopen, dat bij de aanwijzing van de eventueel te ontginnen lagen niet alleen de economie, maar ook de wetenschap en de aesthetica een woordje zullen meespreken.

Als natuur- èn cultuurmonument vragen dringend bescherming de grotten op Curaçao, Aruba en Bonaire 1), die bekend zijn om de druipsteenvormingen en het voorkomen van Indiaansche figuren. Helaas zijn deze grotten op ergerlijke wijze bekrast met handteekeningen van ijdele bezoekers, en het is de hoogste tijd, dat aan dit vandalisme een einde wordt gemaakt. Gelukkig heeft sedert kort het Gouvernement zich het lot dezer ethnologisch zoo interessante objecten aangetrokken. De beste wijze van bescherming zou zijn een cactusheg een eindweegs voor de grot aan te brengen en aan weerszijden te laten aansluiten tegen de steile kalksteenwand. Zoodoende zou niet alleen de grot maar ook een aardig terreintje van het begroeide lagere kalkterras gereserveerd kunnen worden (Hato, Curaçao; Fontein, Aruba; Spelonk, Bonaire). Hierdoor wordt bovendien vermeden, dat de grot ontsierd wordt door een zich aan de ingang bevindende afsluiting.

Bij het begrip ,,Jacht- en Vischreserve" denken we o.m. aan het Lac op Bonaire en de Simsons Bay Lagune van Westelijk St. Maarten.

Objecten voor hydrologische boschreserves kunnen zeer goed gecombineerd worden met natuurreservaten. Vele terreinen zouden als zoodanig kunnen worden aangewezen op alle zes eilanden.

Hill op het nabije St. Kitts - eens ,,the Gibraltar of the West Indies” - op soortgelijke wijze ontstaan.

G. A. F. Molengraaff in zijn ,,Geologie van het eiland St. Eustatius", 1886, wijdde veel aandacht aan de bouw en de vermoedelijke geologische verklaring van deze formatie.

1) Over hun ontstaan leze men het artikel van P. WagenaAR Hummelinck ,,Over grotten en grottenvorming op Curaçao, Aruba en Bonaire", in de W. I. Gids jrg. 25, dl 26, 1943; p. 365. 
Wij willen echter volstaan met het noemen van de krater van Statia's vulkaan, de Quill 1), zijnde een mooi object voor een natuurmonument.

Deze vrijwel cirkelvormige krater (langste as 750 meter, kortste $737 \mathrm{~m}$ ) is als studieterrein voor den geoloog, den botanicus en den zoöloog van groote beteekenis. De bosschen aan de buitenhellingen van de vulkaan vertegenwoordigen eveneens een aanzienlijke waarde en zij behooren als hydrologische reserve te worden beschermd ten behoeve van de landbouwgronden der cultuurvlakte. Een fraai aaneensluitend complex zou zoodoende behouden kunnen blijven, welks instelling economisch, wetenschappelijk en landschappelijk volkomen verantwoord zou zijn.

Bij de inleiding werd de aandacht gevestigd op de interessante cactusflora der drie Benedenwindsche Eilanden. Vele publicaties over deze plantengroep zijn reeds verschenen. Recente onderzoekingen zijn hoofdzakelijk verricht door Dr. P. WAGENAAR HUMMELINCK, die in een reeks artikelen (o.a. in het maandblad

1) In zijn dissertatie (1886) wijdt wijlen Professor G. A. F. MolenGRAAFF een beschouwing aan dit plekje, welke wij - om een beeld te geven van de Quill, en evenzoo om den lezer te laten zien hoe in oude wetenschappelijke verhandelingen lyrische ontboezemingen een plaats kunnen innemen naast geleerde beschrijvingen - hier afdrukken:

„,Van het geheele eiland St. Eustatius is de kraterrand van den hoofdvulkaan zeker het aanlokkelijkste plekje om te vertoeven; hoog woud en koelte, twee zaken, die men in de vlakte te eenenmale mist, zijn hier overvloedig. De geheele kant is bedekt met een weelderig bosch, waarin o.a. groepen van boomachtige Clusia's door hun klimwortels de aandacht trekken en varens en Aroideën overvloedig zijn; geen Cactus of Casha stoort op gevoelige wijze het genieten van de schatten van de tropische plantenwereld. Telkens geeft een kleine opening in het groen verrassende kijkjes, nu eens over het lichtgetinte eiland en de donkerblauwe zee, dan weder in den krater zelve, waar de tallooze schakeeringen van groen van het hooge geboomte slechts bij enkele loodrechte plekken van den binnenwand voor donkere rotspartijen wijken. Een der fraaiste en aangrijpendste vergezichten geniet men van den hoogsten, zuid-oostelijken top van den kraterrand, waar men zich juist tegenover het eiland St. Kitts bevindt.

De binnenwanden van den krater zijn zeer steil en op de meeste plaatsen door talrijke loodrechte kliffen onbeklimbaar. De kraterbodem is tamelijk vlak, doch zeer oneven door de talrijke rotsblokken, die van den kant naar beneden zijn gestort. De geheele oppervlakte is met eene dikke laag teelaarde bedekt, waarin zich eene zeer overvloedige en veelsoortige vegetatie heeft ontwikkeld. De geoloog kan niets beters doen dan hier van zijn arbeid uitrusten en ,,to enjoy the tropics". Heeft hij echter ook maar éen droppel botanisch bloed in de aderen, dan voorzeker zal zijn rust van korten duur zijn, want Flora wenkt hier van alle zijden". 
Succulenta) ons nader vertrouwd heeft gemaakt met de verschillende soorten en hun verspreiding. Zou het niet aardig en ook nuttig zijn een terrein met een fraaie cactusbegroeiïng (en tevens andere typische Curaçaosche planten) te reserveeren als botanisch reservaat? Door de verschillende exemplaren van een naambordje te voorzien, zou tevens een educatief en toeristisch doel gediend zijn. Wellicht is in het kalkgebied van Midden-Curaçao een geschikt terrein te vinden, dat de verschillende kalkterrassen - op zich zelve reeds buitengewoon interessant - omvat.

Zuinig moeten we ook zijn met de nog bestaande broedterreinen van in koloniën nestelende vogels: de flamingo's op Bonaire 1), de reigers en pelikanen (?) op het met mangrove begroeide Rif langs de Zuidkust van Aruba, en de Jan van Genten van de Bovenwindsche Eilanden.

Jan van Genten of „,Brown Boobies” (Sula leucogastra) waren eeuwenlang zeer talrijk op de Nederlandsche Antillen, en we kunnen veilig aannemen, dat de phosphaatafzettingen voor een groot deel ontstaan zijn uit de guano dezer vogels. De laatste groote broedkolonie bevond zich op Klein-Curaçao. Een „Plakaat", uitgevaardigd op 29 Maart 1737, verbood het vangen en dooden, en het rapen der eieren op dit eilandje 2). Hoewel men deze bepaling als de eerste wetgeving op vogelbeschermingsgebied zou kunnen beschouwen, was zij in feite alleen gericht op de vei-

1) Deze vogels broedden tot voor kort regelmatig in het Pekelmeer en het zoutwatermeer Gotó. Ongelukkigerwijze werden ze in 1944 van Bonaire verjaagd door onverantwoordelijk optreden van leden van de U.S.Army (de vogels werden opgeschrikt en opgejaagd door laag overscherende vliegtuigen, en door onnoodige knalpartijen). In 1945 keerden eenige honderden flamingo's tijdelijk terug, en hielden zich toen op bij het Lac, zonder echter hun broedterreinen te betrekken. Na hun vertrek zijn de flamingo's langen tijd niet meer gezien behalve één exemplaar op Gotó en één in het Pekelmeer. De vrees scheen toen niet ongewettigd, dat de flamingo's voor Bonaire verloren zouden zijn. In 1947 is echter een groot aantal teruggekomen: nog in April en Mei werd door fr. M. ARNOLDo een troep van 30-40 stuks in het Gotó-meer gezien, maar géén nesten. Over de toestand in het Pekelmeer tijdens dit broedseizoen (dat in April begint) zijn geen gegevens bekend.

Het verlies der flamingo's op Bonaire zou des te ernstiger zijn, omdat in de loop der tijden deze vogels ook elders van hun broedplaatsen zijn verdreven. Dit was met name het geval met de Venezolaansche eilandjes oostelijk van Bonaire (Las Aves, Los Roques, Orchila) en misschien ook met Klein-Curaçao.

2) De tekst van dit Plakaat komt voor in P. A. EUWENS' opstel ,"Klein-Curaçao", in de W. I. Gids jrg. 7, dl 8, 1926; p. 401. 
ligheid van de scheepvaart. Immers door het groote aantal vogels werden de stuurlieden der schepen bijtijds attent gemaakt op de nabijheid van dit kleine, lage, dikwijls slecht zichtbare eilandje. Het verbod werd echter onvoldoende nageleefd en de kolonie ging hoe langer hoe meer achteruit. Wanneer de laatste der Jan van Genten van Klein-Curaçao werd verdreven, is niet bekend. Indien zij niet reeds eerder waren verdreven, heeft in ieder geval de phosphaat- en guano-ontginning in de zeventiger jaren der vorige eeuw een einde gemaakt aan hun aanwezigheid.

Op het oogenblik broeden Jan van Genten alleen nog in gering aantal op de kleine rotsachtige eilandjes ten Oosten van St. Maarten, de zoogenaamde „Keys”: Guana Key (Pelikan), Hen \& Chicken, Mal Aborder (Molly Beday). Vermoedelijk is ook de Diamond Rock, een kleine, zeer steile rots in zee, ten Noordwesten van Saba, broedplaats van enkele vogels. Er bestaat geen bepaalde handel in booby-eieren, maar toch worden van tijd tot tijd de Keys in het broedseizoen (Juni-Juli) door eierrapers bezocht. Tijdens zulke strooptochten zijn enkele malen ergerlijke gevallen van vernieling van eieren en jonge broedsels voorgekomen. Het is hoognoodig, dat op deze laatste wijkplaats de Jan van Genten zonder overlast van menschen kunnen broeden. Dit kan worden bereikt door de Keys te bestemmen tot vogelreservaat (natuurmonument) en gedurende de broedtijd te laten bewaken.

Niet ver van de Keys ligt op het hoofdeiland St. Maarten het boschrijke Point Blanche-schiereiland, het zuidelijke gedeelte waarvan schrijver graag gereserveerd zou willen zien als refugium voor de intensief vervolgde „Red-tailed Hawk” en de grootere duivensoorten (blue pigeons, mountain doves). Op St. Maarten is dit het eenige Gouvernementsterrein van uitgestrektheid, waar een natuurlijke, zij het ook niet geheel oorspronkelijke houtopstand is.

Bij de bespreking van de te conserveeren terreinen zijn we terecht gekomen bij de vogelbescherming als zoodanig. Vogelbescherming - en in het algemeen faunabescherming - kan niet alleen berusten op het instellen van natuurreservateri en het bewaken van broedterreinen. Ook daarbuiten dienen de soorten krachtens een Vogel- of Faunabeschermings-Verordening bescherming te genieten. In een onlangs gepubliceerd artikel 1) heeft schrijver zijn ideeën uiteengezet omtrent een toekomstige

1) J. H. WeStermanN ,,Bird preservation in the territory of Curaçao", 1946, Uitgaven Natuurwetenschappelijke Studiekring voor Suriname en Curaçao no I (Jaarboek 1945-1946); p. 78. 
Vogelbeschermingswetgeving, waaraan hier een en ander ontleend kan worden.

Het gebiedsdeel bezit reeds een aantal Verordeningen inzake faunabescherming. Op 20 Juli 1926 kwam tot stand de ,Ve r or dening tot bescherming van diersoorten, nuttig voor l and- e n o of tbouw", waarin het verboden werd ,,in het wild levende dieren, nuttig voor land- en ooftbouw, te vangen, te dooden, te vervoeren, te koop aan te bieden, te verkoopen, af te leveren, ten verkoop of ter aflevering in voorraad te hebben of uit te voeren". Evenzoogeldt het verbod om van de in het wild levende vogels ,,de eieren uit te halen, te vernielen, te vervoeren, enz.", en ,,de nesten te verstoren, te vernielen, te verkoopen of af televeren". Slechts kan voor een wetenschappelijk of opvoedkundig doel ontheffing van deze verbodsbepalingen verleend worden.

Op 28 Aug. 1931 werd de bescherming, neergelegd in deze Verordening, uitgebreid tot de diersoorten, ,,die lang zamerhand uitsterven en op welker voortbestaan prijs wordt gesteld", en werd tevens verboden de beschermde dieren ,,in gevangenschap te houden". Oorspronkelijk, in 1926, was de Verordening slechts van toepassing op de Troepialen (Icteridae). Bij de Besluiten van den Gouverneur van 28 Sept. 1931 en 30 Aug. 1934 werd de lijst der beschermde soorten echter aanzienlijk uitgebreid, en wel met het Curaçaosche Hert (Odocoileus gymnotis curassavicus), de Bruine Pelikaan (Pelecanus occidentalis), de Flamingo (Phoenicopterus ruber), de Reigers (Ardeidae), de Tortolica (Chaemepelia passerina), de Kolibries (Trochilidae), de Tjoetjoebi (Mimus gilvus rostratus), de Para-di-Misa (Dendroica ruficapilla), de Moffi (Tiaris bicolor) en de Barica Heel (Coereba uropygialis) 1).

1) De ,,wetenschappelijke” benamingen, gebruikt in de beide Besluiten, zijn ontleend aan een oude beschrijving van Curaçao door den predikant G. J. Simons: „Beschrijving van het eiland Curaçou, uit verschillende bronnen bijeenverzameld" (1868). Zij zijn geheel verouderd en in onbruik geraakt, en in dit artikel vervangen door de moderne nomenclatuur. Op één punt is de lijst van het Besluit van 28 September 1931 bepaaldelijk verwarrend, namelijk waar vermeld staan Certhia longerostris major (Para carpinteer) en Certhia longerostris minor (Para carpinteer chikitoe). Certhia is de genusnaam van de Boomkruiper van Noord-Amerika en Europa, terwijl met „,Para carpinteer" de Curaçaoënaars aanduiden de Nachtzwaluw of Geitemelker (Thermochalcis cayennensis insularis). Moet dus de Nachtzwaluw tot de beschermde vogels worden gerekend?

Bij Besluit van 13 Jan. 1937 is ook de Fazant tot een beschermde soort verklaard. Natuurlijk kan hier alleen sprake zijn van verwilderde geïmporteerde vogels. Overigens wordt in de bestaande beschrijvingen 
Als resultaat van de strikte bescherming namen sommige soorten, in het bijzonder de troepialen en tjoetjoebi's zoodanig in aantal toe, dat bij Land sverordening van 7 Mei 1940 aan den Gouverneur de bevoegdheid werd verleend ,,in het belang van den land- en ooftbouw, ten aanzien van bepaalde dier-en vogelsoorten voor bepaalde eilanden en voor bepaalden tijd bij besluit ontheffing van het verbod" van vangst, jacht, enz. - zooals neergelegd in de Verordening van 1926 - te verleenen. Eenigszins vreemd doet echter de redactie aan, dat in een Verordening, die diersoorten beschermt ,nuttig voor land- en ooftbouw", tevens de bepaling voorkomt, dat aan deze soorten ,,in het belang van den land- en ooftbouw" de bescherming kan worden onthouden!

Op jachtgebied bestaan er nog nauwelijks voorschriften. Het jagen op Gouvernementsgronden is vrij. Jagers hebben geen jachtvergunning noodig, maar alleen een vergunning voor het bezitten van (vuur)wapenen en het dragen dezer op publiek terrein (Wapenverordening van 7 November 1931).

Hoe lofwaardig op zich zelf de bestaande faunabeschermingsverordeningen en -besluiten zijn, toch zijn zij in menig opzicht voor verbetering vatbaar. Schrijver dezes zou gaarne de lijst van beschermde soorten in het belang van de wetenschap en de landbouw aanzienlijk uitgebreid zien. Het meest wenschelijk zou het zijn om - evenals de Vogel- en Jachtwet van Puerto-Rico (1937-1938, 1940) — àlle soorten te beschermen, met uitzondering van eenige met name aan te duiden schadelijke en jaagbare dieren, ten aanzien van welke laatste dan speciale bepalingen in het leven zouden moeten worden geroepen.

Wat de jacht betreft, zou er een gesloten seizoen moeten zijn gedurende dat deel van het jaar, waarin de broed- en voortplantingstijden vallen. Voor de Benedenwindsche Eilanden komt dit in hoofdzaak neer op de maanden October $\mathrm{t} / \mathrm{m}$ April. Voorts zou het verboden moeten zijn om 's nachts met kunstlicht te jagen en om de jacht en de vangst te beoefenen in de onmiddellijke nabijheid van bronnen en zoetwatervijvers; immers deze laatste zijn schaarsch op de eilanden en daardoor is er een belangrijke concentratie van het dierenleven in de directe omgeving ${ }^{1}$ ).

van de dierenwereld van Curaçao niet gerept van fazanten; wel daarentegen van verwilderde pauwen.

1) Dat het jagen in de nabijheid van zoetwaterputten en tankies geen uitzondering is, kan men o.a. constateeren uit twee door bonafide jagers geschreven artikelen over de jacht op Curaçao: B. Jonkers ",Verhandeling over de in het wild levende dieren en de jacht op het eiland Curaçao" (De Nederlandsche Jager jrg. 43, no 46-52; jrg. 44, 
Als jachtwild zijn te beschouwen de konijnen, patrijzen, duiven, strandloopers, plevieren, waterhoenders, eenden en leguanen. De soorten behoorende tot de laatste vier vogelfamilies zijn vrijwel alle trekkers, waarvan sommige in hun broedgebied in Noord-Amerika strikte bescherming genieten. Terecht dienen wij ons dus af te vragen of het wel juist is op deze soorten te jagen terwijl zij trekken naar en van hun overwinteringsgebied. Ook Europa kent het probleem van de bescherming der trekvogels; het is daar door de grootere bevolkingsdichtheid nog urgenter dan in het Westelijk halfrond. Internationale voorziening op dit punt is dringend gewenscht en gewezen moge worden op de te dien aanzien bestaande Conventies voor de bescherming van trekvogels in de U.S.A. en Canada (1916) en in de U.S.A. en Mexico (1936). Het is hier tevens de plaats om nog eens de Convention on Nature Protection and Wild Life Preservation in the Western Hemisphere (1942), te noemen, die-evenzoo het trekvogelvraagstuk aanroert 1).

Alhoewel deze conventie voorloopig alleen openstaat voor onderteekening door de Amerikaansche staten aangesloten bij de „Pan American Union”, doen we er goed aan haar algemeene richtlijnen reeds thans in ons gebiedsdeel te volgen.

Samenwerking binnen het Caraïbische gebied door middel van de in 1946 gevormde Caribbean Commission en de daaronder ressorteerende Caribbean Research Council is evenzoo hoogstwensche-

5-9; Mei-Aug. 1938), en M. B. Gorsira Azn. „,De Curaçaosche Nimrod" (Weekblad Curaçao, 30 Nov. en 7 Dec. I940). De laatste auteur hoewel volgens zijn beschrijvingen een weidelijk jager - schrijft notabene van de tortolica, waarvan hij weet, dat het een bij Verordening beschermde soort is: „Als aanhanger van het motto: ,leef en laat leven", zou ik toch wel wat totolikas willen schieten, wanneer ik zin heb in een pastei bereid met het vleesch van deze duiven. Ik heb de overtuiging, dat ik hiermede deze vogels niet help uitroeien. Wil men een pastei hebben, waarvan het heele huisgezin mee kan genieten, dan zijn er wel 30 à 40 totolika's noodig. Mogen deze vogels niet te veel aan patronen kosten, dan ga ik bij een open put zitten en paf ze, 3-10 tegelijk, neer, als ze water komen drinken." (!) Het is op z'n zachtst gezegd bevreemdend, dat in de pers dergelijke onwettige jachtpraktijken kunnen worden aanbevolen.

1) Art. 7: ,,The Contracting Governments shall adopt appropriate measures for the protection of migratory birds of economic or aesthetic value or to prevent the threatened extinction of any given species. Adequate measures shall be adopted which will permit, in so far as the respective governments may see fit, a rational utilization of migratory birds for the purpose of sports as well as for food, commerce and industry, and for scientific study and investigation." 
lijk. Dit geldt niet alleen voor de trekkende vogels maar ook voor de verschillende soorten zeeschildpadden, die in het geheele gebied al te zeer vervolgd worden om de eieren, het vleesch en de karet, en die als gevolg daarvan op vele eilanden praktisch verdwenen zijn. In vroeger jaren waren verschillende zandige kusten op de Nederlandsche Antillen een legplaats dezer dieren, terwijl thans schildpadden er zelden aan land komen. Strikte reserveering van broedstranden zou misschien na eenige jaren de schildpadden terugbrengen. Voorstellen tot bescherming zijn indertijd gedaan door Pater Euwens en Dr. BoEke 1), terwijl het zeer recente „Rapport Welvaartsplan Nederlandsche Antillen 1946" van Prof. Ir. D. DResden en Prof. Dr. Ir. J. GOUDRIAAN op grond van BOEKE's rapport de schildpaddenkweekerij aanbeveelt.

Behalve voor de jachtdieren moet er een speciale regeling gemaakt worden voor de zgn. schadelijke dieren. Bij de vaststelling of een soort al dan niet schadelijk is, moeten we wel uiterst voorzichtig zijn. We weten immers nog zoo heel weinig af van de levenswijze en de voeding der in het wild levende zoogdieren en vogels. Oppervlakkig gezien, bijvoorbeeld, lijken de roofvogels zeer schadelijk, omdat zij voor-de-landbouw-nuttige vogels als prooi hebben en zich ook niet ontzien om kippenkuikens te „,stelen”. Weinig beseffen echter de meesten onzer welk een nuttige rol de roofvogels spelen bij het bewaren van het evenwicht in de natuur. De Kini-kini's en Killy-killy's (Falco sparverius) verdelgen tallooze sprinkhanen en voeden zich met muizen en hagedissen; zij zijn derhalve nuttige vogels. De Wara-wara (Polyborus cheriway) is een aasvreter en heeft als zoodanig een zeer nuttige taak. In het nabuurland Venezuela komt deze vogel voor op de lijst der beschermde soorten (Annex van de „Western Hemisphere Convention"), tezamen met andere aasvogels zooals de Zamuro's en Oripopo's (deze laatste behooren tot de familie der gieren: Coragyps atratus foetens, Cathartes urubitinga en Cathartes aura ruficollis). Dat de Wara-wara ook wel lammeren en jonge geitjes tot prooi kiest, kan men hem bij het huidige ,wilde" systeem van veeweide - waarbij zeer vele dieren ook om andere redenen omkomen - bepaald niet kwalijk duiden. De soorten van het geslacht Buteo, de Witstaart-Valk

1) P. A. Euwens ,,Schildpadden”, Bonaire-nummer van Neerlandia jrg. $I I, 1907$. J. BoEKE ,, Rapport betreffende een voorloopig onderzoek naar den toestand van de visscherij en de industrie van zeeproducten in de Kolonie Curaçao", dl 1, 1907. 
(Buteo albicaudatus) en de „Red-tailed Hawk” (Buteo jamaicensis), zijn waarschijnlijk de meest vervolgde roofvogels van de Nederlandsche Antillen, omdat zij in een kwaad gerucht staan als kuikendieven. Het aantal exemplaren is echter zoo gering, dat zij als uitstervende soort een, althans gedeeltelijke, bescherming behoeven, zoowel bij Besluit als in uitgestrekte natuurreservaten.

Zeer schadelijk echter zijn zonder twijfel de verwilderde honden en katten en de op St. Maarten voorkomende Zuid-Aziatische Mongoose (Herpestes mungo). De mongoose is omstreeks 1885 geimporteerd ter bestrijding der ratten en muizen in de toenmalige suikerplantages. De suikercultuur is reeds sedert jaren verdwenen, en zoowel de ratten als de mongoose hebben zich sterk vermenigvuldigd, tot groote schade van de vogelstand. Vogelbescherming zou er ten zeerste mee gebaat zijn, indien stelselmatig deze verwilderde honden, katten en mongoosen zouden worden weggeschoten of weggevangen.

Wij zijn thans aan het einde dezer verhandeling gekomen en hopen, dat bij den lezer - voorzoover nog geen overtuigd natuurbeschermer - het besef is gewekt, dat het behoud van de natuur, in al zijn aspecten, een wezenlijke voorwaarde is voor een harmonische ontwikkeling van land en volk der Nederlandsche Antillen. Wij mogen ons gelukkig prijzen, dat Gouvernementskringen het belang ervan duidelijk inzien. Moge het zoover komen, dat door onderwijs en door voorlichting in de pers ook de bevolking in al haar geledingen natuurbescherming naar waarde gaat schatten.

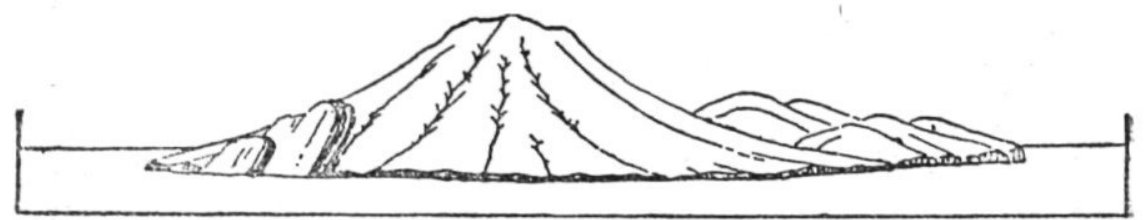

Schets van St. Eustatius. Sugarloaf en White Wall in steile stand rustend tegen het lichaam van de Quill-vulkaan (naar Davis).

Afbeeldingen. Fig. 7, 8 en 9 zijn van S. Fischer te Willemstad, fig. 4 van fr. M. Arnoldo, de overigen van P. WagenaAr Hummelinck. De cliché's van fig. 7, 8 en 9 werden door de uitgevers van Ardea, dat van de tekstafbeelding door die van de Leidsche Geol. Mededeelingen, die van fig. 2, 3 en 5 door de drukkers van Realino's boekje over ,,De Nederlandse Antillen"' in bruikleen afgestaan. 


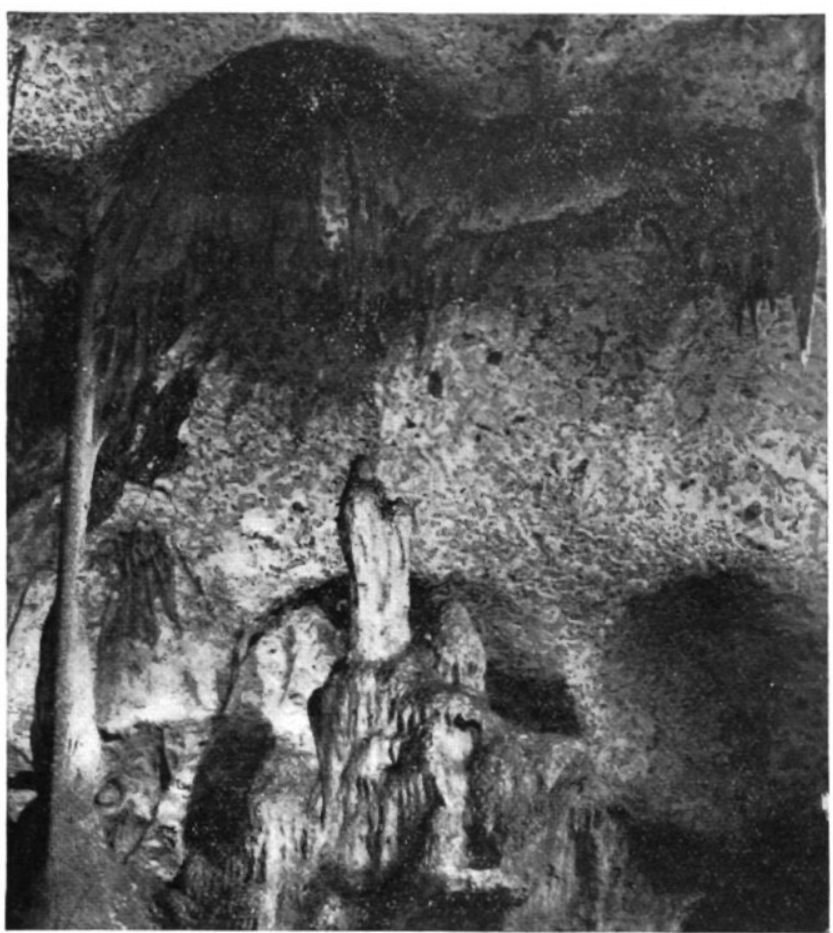

Fig. 1. Druipsteengroepje „Madonna met Kind” in de groote hal van de Grot van Hato, Curaçao. Het natuurlijk beeld van de „Virgen” is, zonder voetstuk, $70 \mathrm{~cm}$. hoog.
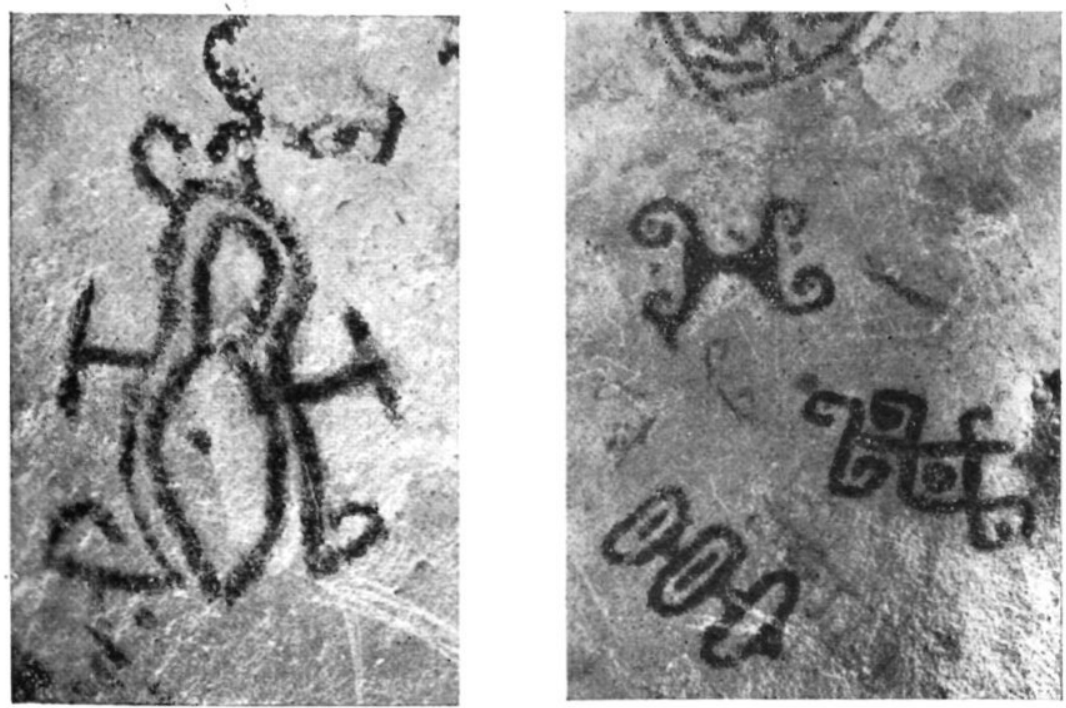

Fig. 2 en 3. Roodbruine Indianenteekeningen op het plafond van de Grot van Fontein op Aruba, die beschermd moeten worden tegen vandalisme. 
Plaat 2

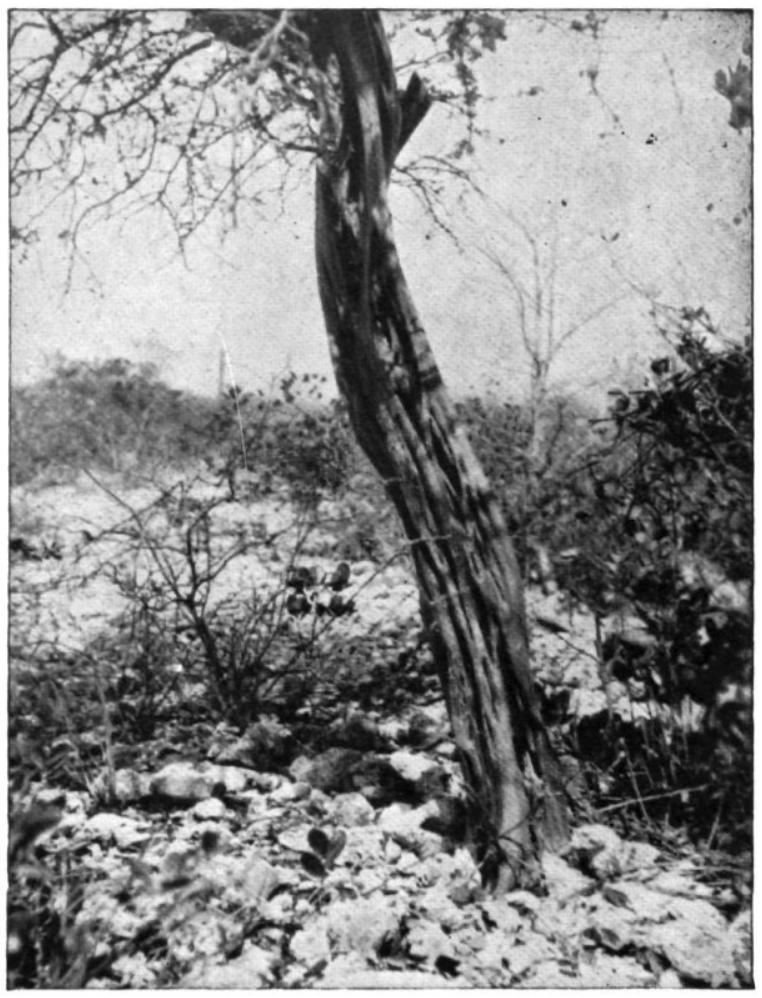

Fig. 4. De merkwaardig gevormde stam van het Verfhout (brasya of campèshi), op het rif achter Marie Pompoen, Curaçao. Verfhout werd vroeger in groote hoeveelheden uitgevoerd.

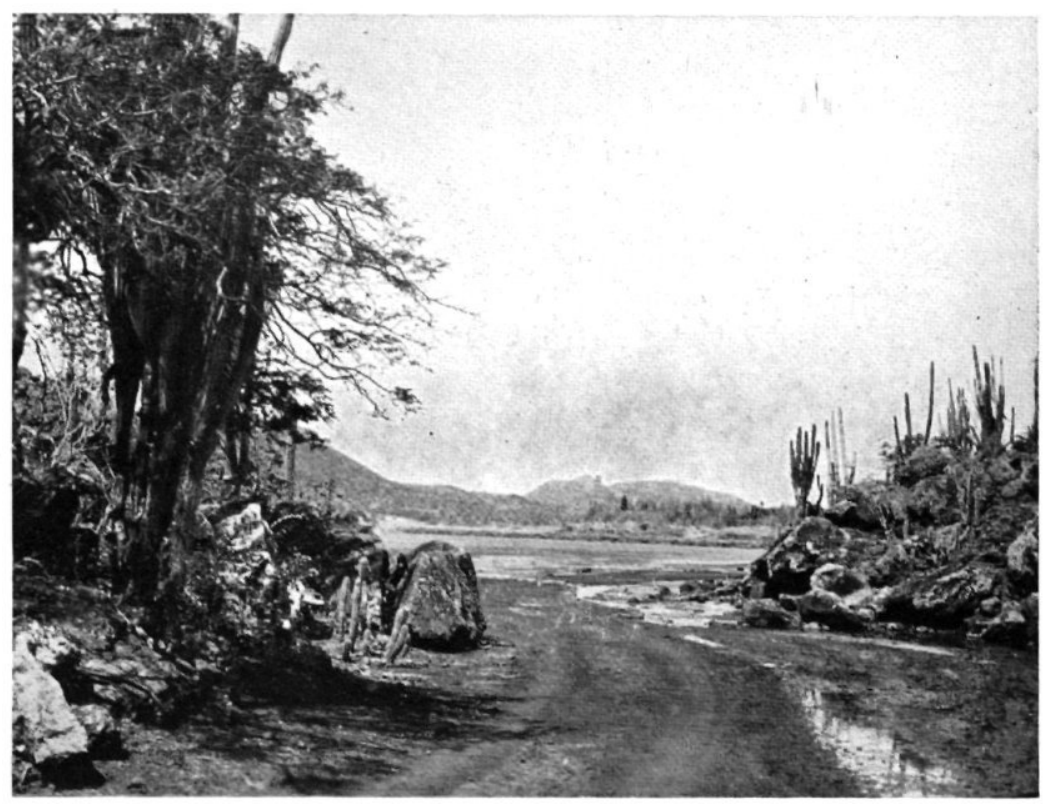

Fig. 5. Weg van Rincón naar Slagbaai, bij het zoutwatermeer Gotó, op N. W. Bonaire. Vóór 1944 waren op Gotó flamingo's regelmatige verschijningen. 
Plaat 3

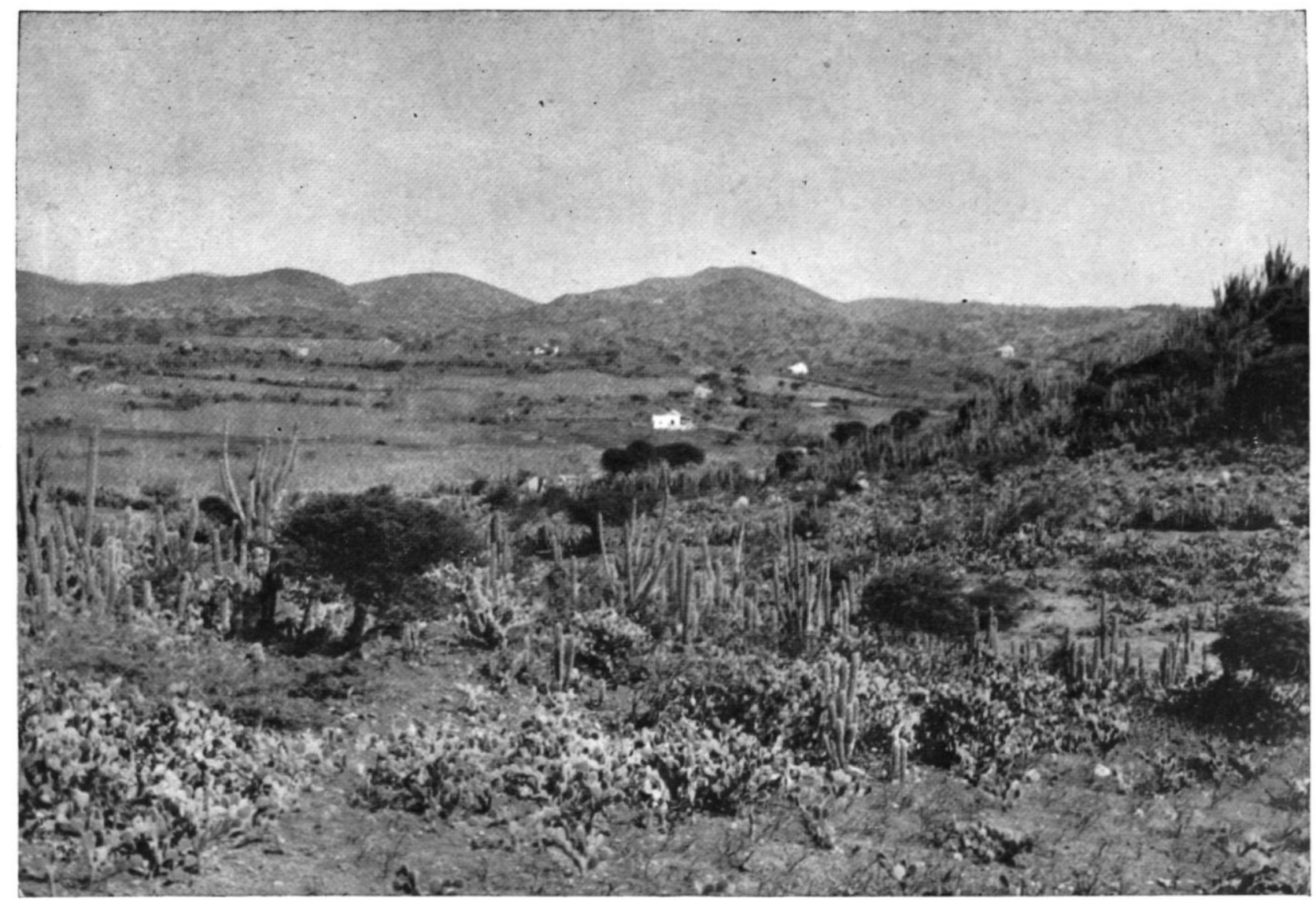

Fig. 6. Typisch Arubaansch landschap, gezien van de nienwe weg tusschen Spaansch Lagoen en Santa Cruz in de richting van de Jamanota $(188 \mathrm{~m})$ en de meer noordelijk gelegen heuvels. De voorgrond is begroeid met cactussen (tuna en datoe) en hier en daar een divi-divi-boom; het vlakke terrein daarachter is beplant met „,kleine mais". 


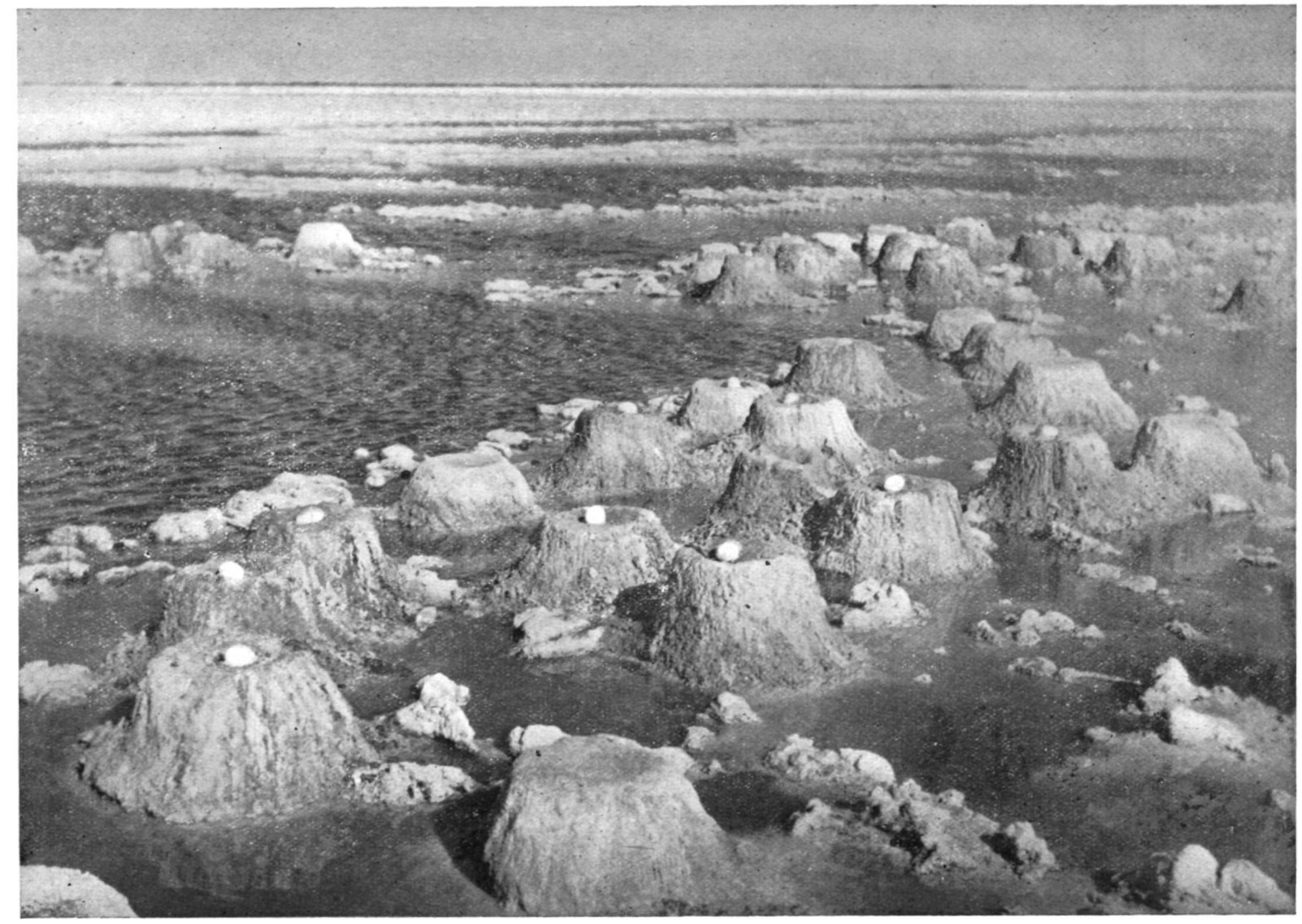

Fig 7. Pekelmeer op Zuid-Bonaire met de uit slik opgebouwde flamingo-nesten, elk met één ei. 


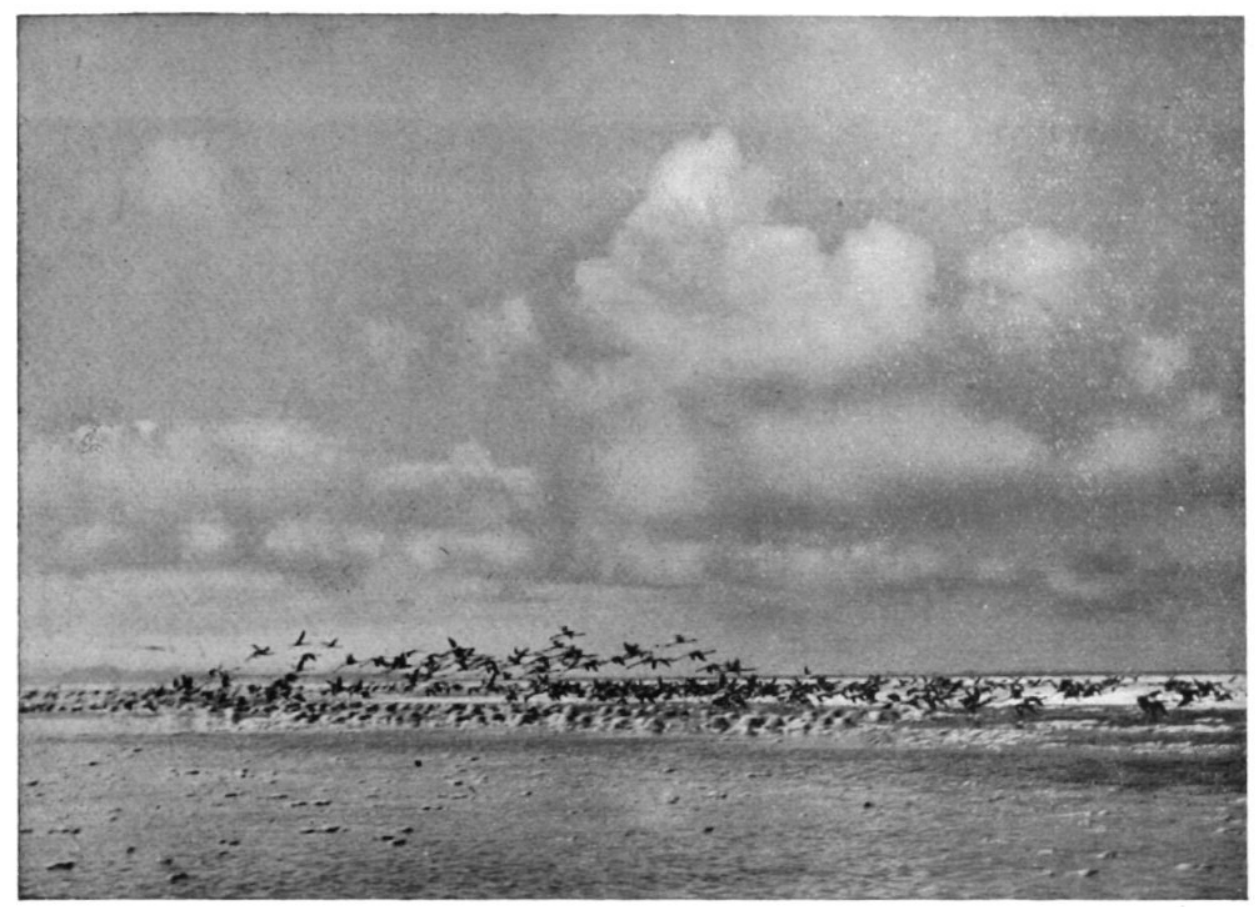

Fig. 8. Pekelmeer op Zuid-Bonaire met opvliegende flamingo's. Flamingo's zijn bij Landsverordening beschermde vogels. Helaas werden zij in 1944 van het eiland verjaagd door onverantwoordelijk optreden van leden van de U.S. Army.

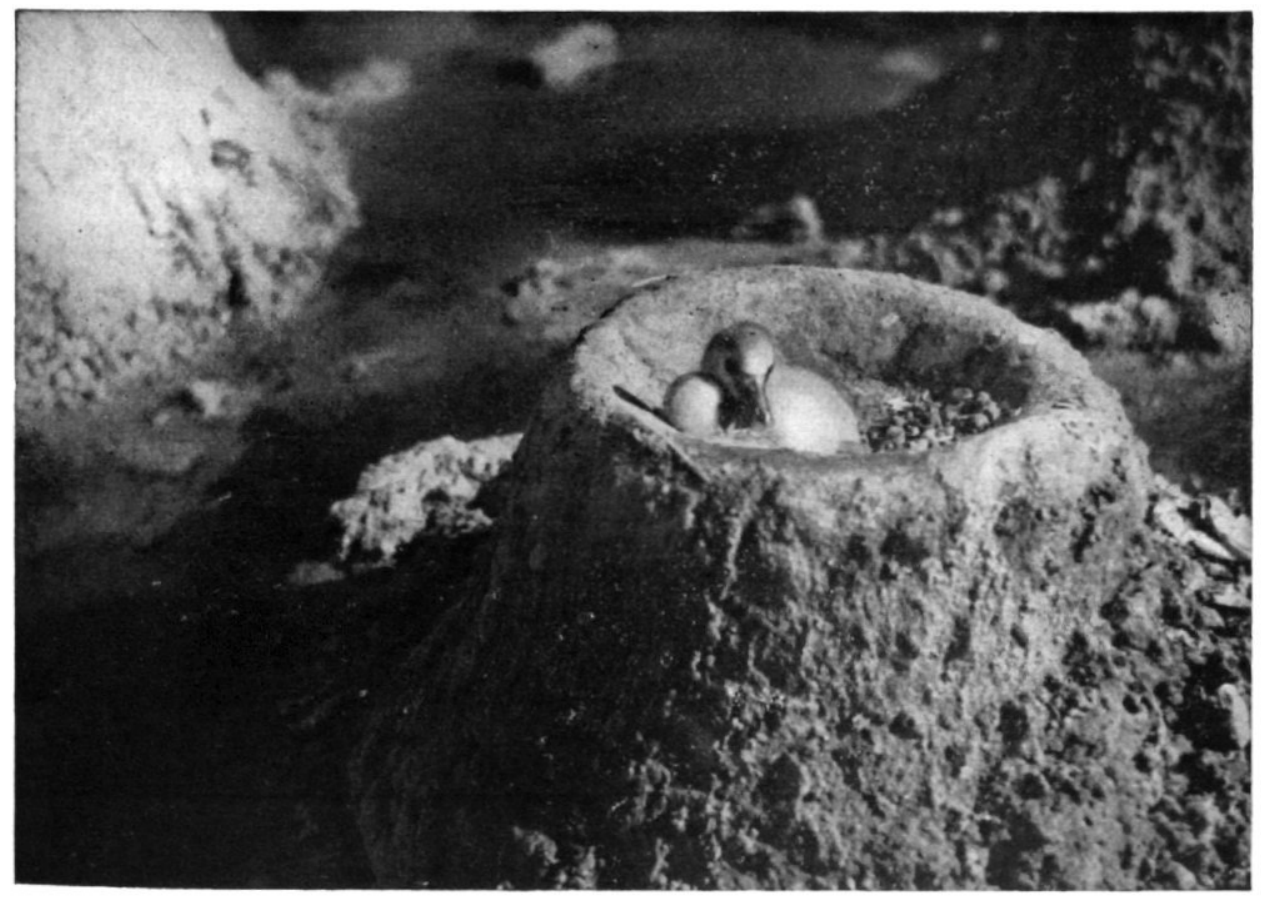

Fig. 9. Flamingo-nest met donskuiken, in het Pekelmeer. 
Plaat 6

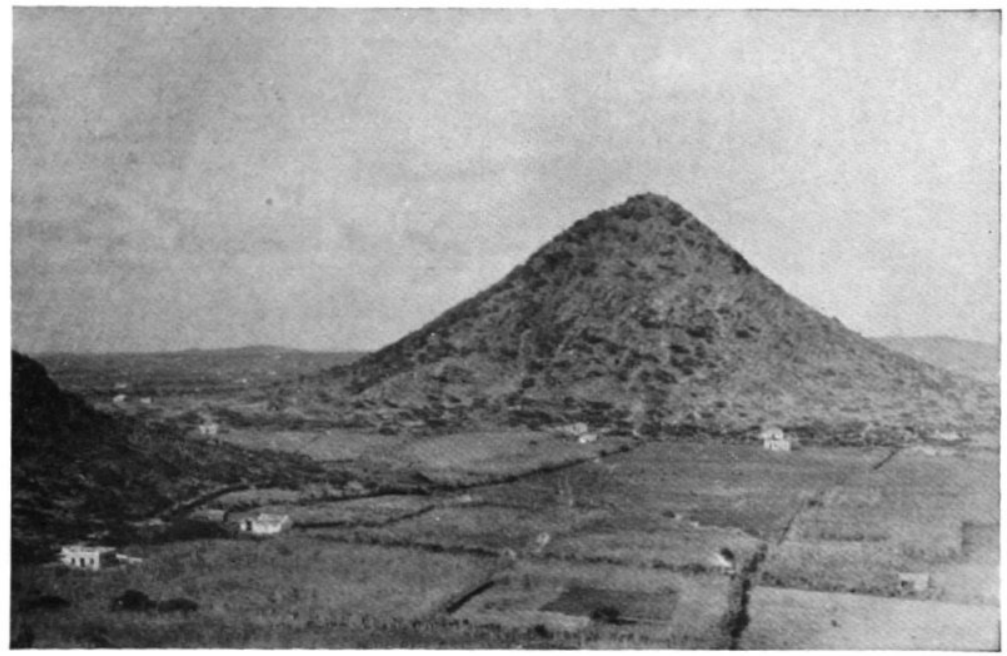

Fig. 10. De Hooiberg $(165 \mathrm{~m})$ op Aruba, een geologisch en landschappelijk monument, gezien van de Seroe Canashito. De vlakte is beplant met „kleine mais”.

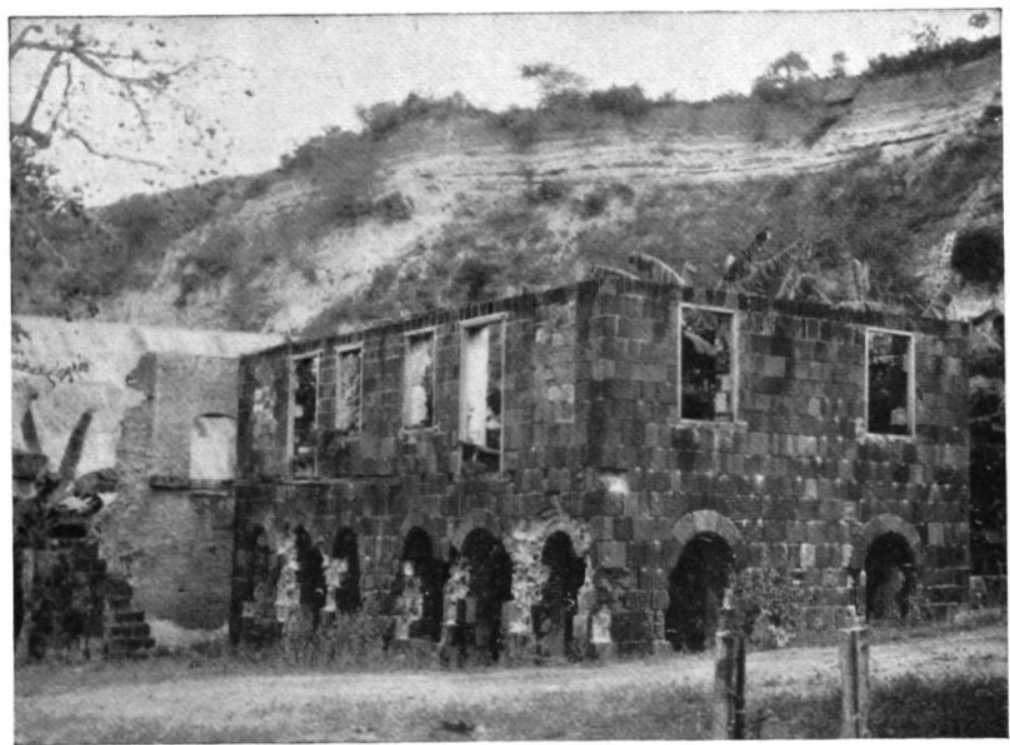

Fig. 11. Strand van St. Eustatius met de ruïne van een gebouw van de voormalige benedenstad. Op de achtergrond het steile klif met horizontale tuflagen van de Quill-vulkaan. - Oranjestad bezit nog vele historisch-belangwekkende overblijfselen uit de tijd toen Statia de Gouden Rots heette. Deze dienen als Cultuurmonumenten voor het nageslacht bewaard te worden. 